\title{
ANALISIS PENGARUH KOMORBID, USIA, DAN JENIS KELAMIN TERHADAP MENINGKATNYA ANGKA KEMATIAN PADA MASA PANDEMI COVID-19
}

Maulidya Nanda Nur Illah

Universitas Islam Negeri Sunan Ampel Surabaya

E-mail: maulidyannd15@gmail.com

Diterima:

28 September

2021

Direvisi:

11 Oktober 2021

Disetujui:

15 Oktober 2021

\section{Abstrak}

Dunia sedang dilanda wabah virus corona. Virus tersebut ditemukan pada akhir desember 2019. Kini, virus corona telah menyebar ke berbagai belahan negara di dunia termasuk Indonesia. Hari demi hari, angka kasus terkonfirmasi positif Covid-19 semakin meningkat sehingga pada tanggal 11 Maret 2020 ditetapkan sebagai pandemi global oleh WHO. Pandemi tersebut berdampak langsung terhadap berbagai aspek kehidupan masyarakat seperti meningkatnya angka pengangguran, angka kemiskinan, dan angka kematian. Tujuan dari penelitian ini adalah untuk mengetahui pengaruh komorbid, usia, dan jenis kelamin terhadap meningkatnya angka kematian pada masa pandemi Covid-19 selama periode Januari-Juli 2021 di Jl. Raya Lontar RW.01, Sambikerep, Surabaya. Teknik pengumpulan data menggunakan metode wawancara. Berdasarkan penelitian kali dapat diketahui bahwa kematian selama masa pandemi Covid-19 lebih banyak disebabkan paparan virus corona. Adanya penyakit penyerta (komorbid) dapat memperparah kondisi penderita Covid-19. Komorbid yang sering ditemukan adalah hipertensi dan kardiovaskular. Laki-laki berusia 45-60 tahun rentan terpapar Virus Corona bahkan mengalami perburukan klinis sehingga berpotensi meningkatkan angka kematian selama masa pandemi Covid-19.

Kata kunci: Covid-19, Komorbid, Usia, Jenis kelamin

\section{Abstract}

The world is being hit by the coronavirus. The virus was discovered in late December 2019. Now, the corona virus has spread to various parts of the world including Indonesia. Day by day, the number of positively confirmed cases of Covid-19 is increasing so that on March 11, 2020 it was designated a global pandemic by WHO. The pandemic has a direct impact on various aspects of people's lives such as rising unemployment, poverty, and mortality. The purpose of this study was to find out the influence of comorbids, ages, and genders on the increasing mortality rate during the Covid-19 pandemic during the period January-July 2021 at Jl. Raya Lontar RW.01, Sambikerep, Surabaya. Data collection techniques using interview methods. Based on research times it can be known that deaths during the Covid-19 pandemic are more due to exposure to the corona virus. The presence of comorbid diseases can aggravate the condition of Covid-19 sufferers. Comorbids that are often found are hypertension and cardiovascular. Men aged 45-60 years are 

clinical worsening so as to potentially increase mortality during the Covid-19 pandemic.

Keywords: Covid-19, Comorbid, Age, Gender

\section{Pendahuluan}

Pada akhir Desember 2019, ditemukan virus jenis baru yang disebut Covid-19 oleh WHO. Awalnya, virus jenis baru tersebut diberi nama 2019 novel Coronavirus (2019-nCoV) (Yuliana, 2020). Virus corona termasuk dalam family Coronaviridae dan ordo Nidovirales. Virus tersebut berasal dari Wuhan, Tiongkok. Virus corona merupakan virus yang menular. Penularan virus ini ditengarai berkaitan dengan penjualan daging yang berasal dari binatang liar atau penangkaran hewan di pasar makanan laut Wuhan (Ridlo, 2020). Penularan tersebut kemungkinan berasal dari kelelawar. Hal ini dikarenakan 96\% secara genom mirip dengan coronavirus kelelawar (BatCoV RaTG13) (Satria, Tutupoho, \& Chalidyanto, 2020). Kini, virus tersebut telah menyebar ke berbagai belahan negara di dunia termasuk Indonesia. Kasus Covid-19 di Indonesia pertama kali ditemukan pada tanggal 2 Maret 2020 (Utama et al., 2021). Sebaran pandemi Covid-19 di Negara Indonesia telah meluas di 24 provinsi meliputi Bali, Banten, Yogyakarta, Jakarta, Jambi, Jawa Barat, Jawa Tengah, Jawa Timur, Kalimantan Barat, Kalimantan Timur, Kalimantan Tengah, Kalimantan Selatan, Kep. Riau, Nusa Tenggara Barat, Sumatera Selatan, Sumatera Utara, Sulawesi Utara, Sulawesi Tenggara, Sulawesi Selatan, Lampung, Riau, Maluku Utara, Maluku dan Papua. Hari demi hari, angka kasus terkonfirmasi positif Covid-19 semakin meningkat sehingga pada tanggal 11 Maret 2020 ditetapkan sebagai pandemi global oleh WHO. Pada tanggal 31 Maret 2020, sebanyak 1.528 terkonfirmasi Covid-19 dengan 136 kasus kematian. Tingkat mortalitas Covid-19 di Indonesia sebesar 8,9\%, persentase tersebut merupakan yang tertinggi di Asia Tenggara (Susilo et al., 2020).

Pandemi Covid-19 dalam kurun waktu satu tahun terakhir telah menjadi pusat perhatian seluruh penduduk dunia. Pandemi tersebut berdampak langsung terhadap berbagai aspek kehidupan masyarakat seperti meningkatnya angka pengangguran, angka kemiskinan, dan angka kematian. Pada 20 Mei 2020, kasus terkonfirmasi positif Covid19 di dunia tercatat 4.9 juta lebih dengan jumlah kasus kematian lebih dari 326 ribu atau mortality rate 15,2\% (Rizal, Afrianti, \& Abdurahman, 2021). Tingginya tingkat kematian akibat virus corona dapat disebabkan oleh kurangnya kesadaran dari masing-masing individu terhadap virus corona, fasilitas kesehatan yang kurang memadai, peraturan pemerintah yang belum efektif, usia rentan, dan riwayat penyakit (Ilpaj \& Nurwati, 2020). Penderita Covid-19 dapat mengalami perburukan klinis bahkan mengakibatkan kematian karena dipengaruhi faktor masalah kesehatan sebelumnya (Mujiburrahman, Riyadi, \& Ningsih, 2020). Orang dengan penyakit penyerta (komorbid) seperti hipertensi, diabetes melitus, dan penyakit jantung akan sangat rentan terpapar virus corona sehingga berpotensi besar meningkatkan risiko kematian. Berdasarkan data dari kasus yang meninggal, sebagian besar mempunyai lebih dari satu penyakit (Larasati, 2021).

Peran pemerintah dalam menekan laju penyebaran kasus Covid-19 antara lain menetapkan beberapa kebijakan seperti Pembentukan Komite Penanganan Covid-19 dan Pemulihan Ekonomi Nasional, menghentikan seluruh penerbangan dari Cina ke Indonesia, serta mengeluarkan kebijakan pelarangan mudik bagi perantau di berbagai daerah ke daerah asal mereka. Namun, berbagai kebijakan tersebut belum mampu menekan laju penyebaran Covid-19 di Indonesia. Hal ini mendasari pemerintah mengambil kebijakan Pembatasan Sosial Berskala Besar (PSBB) yang tertuang dalam 
Peraturan Menteri Kesehatan Republik Indonesia Nomor 9 Tahun 2020 Tentang Pedoman Pembatasan Sosial Berskala Besar dalam Rangka Percepatan Penanganan Covid-19 (Goma, 2021). Kemudian pemerintah memberlakukan istilah baru untuk menekan penyebaran Covid-19 pada daerah berisiko tinggi dengan sebutan PPKM (Pemberlakuan Pembatasan Kegiatan Masyarakat).

Berdasarkan uraian latar belakang diatas, peneliti ingin melakukan penelitian dengan tujuan untuk mengetahui pengaruh komorbid, usia, dan jenis kelamin terhadap meningkatnya angka kematian pada masa pandemi Covid-19. Manfaat dari penelitian ini sebagai tambahan informasi mengenai peningkatan angka kematian akibat adanya virus covid-19

\section{Metode Penelitian}

Kegiatan penelitian dilakukan pada tanggal 09 Agustus 2021 di Jl. Raya Lontar RW.01, Sambikerep, Surabaya. Penelitian dilaksanakan dengan menerapkan protokol kesehatan seperti menjaga jarak dan memakai masker. Desain penelitian ini menggunakan metode kuantitatif sehingga data disajikan dalam bentuk angka. Teknik pengumpulan data yang digunakan adalah metode wawancara. Pewawancara terlebih dahulu menyiapkan daftar pertanyaan yang akan diajukan terhadap narasumber.

\section{Hasil dan Pembahasan}

Data kematian selama masa pandemi periode Januari-Juli 2021 di Jl. Raya Lontar RW. 01, Sambikerep, Surabaya disajikan dalam Tabel 1.

Tabel 1. Data Kematian selama Masa Pandemi Periode Januari-Juli 2021 di Jl. Raya Lontar RW. 01, Sambikerep, Surabaya.

\begin{tabular}{lcc}
\hline \multicolumn{1}{c}{ Variabel } & $\begin{array}{c}\text { Jumlah } \\
(\mathbf{n})\end{array}$ & $\begin{array}{c}\text { Prosentase } \\
(\boldsymbol{\%})\end{array}$ \\
\hline Jenis Kelamin & 13 & 61.9 \\
• Laki-laki & 8 & 38.1 \\
• Perempuan & & \\
\hline Penyebab Kematian & 3 & 14.3 \\
- Covid-19 tanpa komorbid & & \\
$\quad$ <50 Tahun & 4 & 19 \\
- Covid-19 tanpa & & \\
$\quad$ komorbid>50 Tahun & 1 & 4.8 \\
- Covid dengan komorbid & & 33.3 \\
$\quad$ kardiovaskuler & 7 & 9.5 \\
- Sesak nafas & 2 & 4.8 \\
- Demam & 1 & 4.8 \\
- Lambung & 1 & 9.5 \\
- Gegar otak & 2 & \\
- Usia & & \\
\hline
\end{tabular}

Berdasarkan penelitian kali ini dapat diketahui bahwa meningkatnya angka kematian selama masa pandemi Covid-19 lebih banyak disebabkan paparan Virus Corona. Dari data tersebut dapat diketahui bahwa terdapat penderita Covid-19 dengan komorbid. Menurut narasumber, komorbid yang dialami adalah hipertensi dan kardiovaskular. Adanya komorbid dapat menentukan prognosis penderita Covid-19. Hal ini diduga karena kondisi kesehatan sebelumnya mempengaruhi tingkat keparahan penderita Covid-19. Komorbid hipertensi dan kardiovaskular sering ditemukan pada penderita Covid-19. Hal ini terbukti pada studi di Tiongkok terdapat 44.672 pasien 
terkonfirmasi COVID-19 melaporkan bahwa 12,8\% pasien memiliki riwayat hipertensi dan 4,2\% pasien memiliki riwayat penyakit kardiovaskular (Willim, Ketaren, \& Supit, 2020). Kedua komorbid tersebut berpotensi meningkatkan kematian. Hal ini selaras dengan pernyataan Steven, yang mengatakan bahwa pasien dengan hipertensi memiliki peningkatan risiko sebanyak dua kali lipat untuk mengalami keadaan parah ataupun memerlukan intensive care unit (ICU), sedangkan pasien dengan penyakit kardiovaskular memiliki peningkatan risiko sebanyak tiga kali lipat (Tarigan, 2021). Menurut Gunawan et al (2021), mengungkapkan bahwa hipertensi memiliki hubungan dengan Covid-19. Dengan demikian, adanya penyakit penyerta (komorbid) hipertensi akan memperparah infeksi Covid-19 bahkan bisa menjadi patogenesis terjadinya infeksi Covid-19.

Virus tersebut akan mengikat Angiotensin converting enzyme 2 (ACE2) yang ada di paru. Sedangkan, adanya komorbid kardiovaskular berpotensi meningkatkan kematian pada pasien Covid-19 karena ekspresi ACE2 yang lebih tinggi pada penderita penyakit kardiovaskular (Willim et al., 2020). Penyakit kardiovaskular merupakan pertanda percepatan proses gangguan imunologi akibat usia dan berkorelasi secara tidak langsung dengan prognosis Covid-19 sehingga penyakit ini termasuk komorbid terbanyak pada penderita Covid-19, SARS, dan MERS. Selain itu, pada penelitian ini ditemukan lebih banyak kematian akibat Covid-19 tanpa komorbid (Hasanah et al., 2020). Gejala yang dialami berupa kelelahan, batuk, dan, demam. Menurut narasumber, rata-rata penderita Covid-19 tanpa komorbid meninggal dalam rentang waktu 14 hari. Jangka waktu antara munculnya gejala Covid-19 hingga berujung kematian berkisar antara 6-41 hari dengan rata-rata 14 hari (Kangdra, 2021). Rentang waktu tersebut bergantung pada sistem imun dan umur penderita Covid-19. Faktor lain yang menjadi penyebab tingginya mortalitas selama masa pandemi Covid-19 meliputi sesak nafas dan demam. Faktor tersebut merupakan gejala dari infeksi Covid-19. Namun, orang-orang yang meninggal karena gejala-gejala tersebut tidak melakukan pemeriksaan untuk mendeteksi paparan Covid-19 sehingga tidak dapat diketahui apakah orang-orang tersebut terinfeksi Covid-19 atau tidak.

Tabel 1 menunjukkan bahwa laki-laki berisiko tinggi terpapar Virus Corona bahkan mengalami kematian. Hal tersebut disebabkan oleh faktor biologis dan gaya hidup. Secara biologis, tingkat imunitas laki-laki lebih rendah dibandingkan perempuan. Sedangkan, gaya hidup yang mengakibatkan laki-laki berisiko tinggi terpapar Virus Corona bahkan mengalami kematian adalah kebiasaan merokok. Menurut Feni Fitriani, seorang dokter spesialis Paru dari Indonesia menyatakan bahwa perokok dan penghisap vape sudah mengalami kerentanan di saluran pernafasannya sehingga mudah terpapar Virus Corona. Pernyataan tersebut diperkuat oleh Amin Soebandrio, Kepala Lembaga Biologi dan pendidikan Tinggi Eijkman yang mengatakan bahwa merokok dapat mengubah sel paru menjadi lebih rentan terhadap infeksi SARS-COV2 melalui peningkatan reseptornya yaitu molekul ACE2. Peneliti USA, China, dan WHO juga mengungkapkan bahwa kaum laki-laki berisiko tinggi terkena Virus Corona. Berdasarkan data pasien yang dirawat di Kota Wuhan menunjukkan lebih banyak kaum laki-laki yang terinfeksi Virus Corona bahkan Chinese Center for Disease Control and Prevention menyatakan laki-laki yang mengalami Covid-19 memiliki risiko meninggal dua kali lebih tinggi daripada wanita.

Temuan tersebut juga terbukti di Negara Italia, dimana tingkat kematian pada lakilaki jauh lebih tinggi dibandingkan wanita (Siagian, 2020). Selain itu, laki-laki rentan mengalami Covid-19 dikarenakan laki-laki cenderung lebih banyak berada di luar rumah, baik untuk bekerja maupun kegiatan lainnya (Hidayati, 2020). Wanita lebih terproteksi dari Covid-19 dibandingkan laki-laki. Hal tersebut dikarenakan wanita memiliki 
kromosom $\mathrm{x}$ dan hormon seks seperti progesteron yang memainkan peranan penting dalam imunitas bawaan dan adaptif. Selain itu, wanita biasanya memiliki tingkat pengetahuan lebih tinggi dibandingkan laki-laki terutama epidemiologi dan faktor risiko Covid-19.

Pada penelitian ini, usia yang rentan terpapar Virus Corona hingga mengalami kematian berkisar antara 45-60 tahun. Covid-19 menginfeksi semua kelompok umur, akan tetapi median dari umur yang terinfeksi sekitar 47-59 tahun. Risiko terinfeksi Virus Corona semakin meningkat ketika seseorang memasuki usia 40 tahun. Hal tersebut dikarenakan kondisi imunitas seseorang yang cenderung menurun sehingga kerentanan terhadap patogen semakin tinggi. Selain itu, usia 45-60 tahun mempunyai tingkat produktifitas dan mobilitas yang tinggi. Dengan demikian, kondisi ini memungkinkan bagi usia tersebut rentan terinfeksi Virus Corona. sebagian besar kematian akibat Covid19 terjadi terutama pada usia $>50$ tahun (Isna \& Ragil, 2020). Hal tersebut disebabkan oleh beberapa hal, antara lain orang berusia lanjut memiliki masalah kesehatan jangka panjang sehingga lebih berisiko ketika terkena virus, daya tahan tubuh seseorang berkurang ketika menginjak usia senja sehingga sulit melawan infeksi, lapisan pada paru kurang elastis pada masa tua sehingga penyakit seperti Covid-19 cukup mematikan, serta inflamasi pada orang usia senja bisa lebih membahayakan dan menyebabkan kerusakan organ. Hasil tersebut diperkuat dengan penelitian Willim et al (2020), yang menunjukkan data bahwa mortalitas Covid-19 meningkat seiring bertambahnya usia dengan persentase CFR $1,3 \%$ pada pasien usia 50-59 tahun, 3,6\% pada pasien usia $60-69$ tahun, $8 \%$ pada pasien usia 70-79 tahun, serta $14,8 \%$ pada pasien usia $\geq 80$ tahun.

\section{Kesimpulan}

Berdasarkan penelitian kali ini, dapat diketahui bahwa kematian selama masa pandemi Covid-19 lebih banyak disebabkan paparan Virus Corona. Adanya penyakit penyerta (komorbid) dapat memperparah kondisi penderita Covid-19. Komorbid yang sering ditemukan adalah hipertensi dan kardiovaskular. Laki-laki berusia 45-60 tahun rentan terpapar Virus Corona bahkan mengalami perburukan klinis sehingga berpotensi meningkatkan angka kematian selama masa pandemi Covid-19.

\section{Bibliografi.}

Goma, Edwardus Iwantri. (2021). Dampak Covid-19 Terhadap Isu Kependudukan di Indonesia. Geodika: Jurnal Kajian Ilmu Dan Pendidikan Geografi, 5(1), 33-42.

Hasanah, Dian Yaniarti, Nauli, Siti Elkana, Prima Putri, Vebiona Kartini, Arifianto, Habibie, Suryana, Nana Maya, Suryani, Lita Dwi, Aditya, Wahyu, \& Probodewi, Paskariatne. (2020). Gangguan Kardiovaskular pada Infeksi COVID 19. Indonesian Journal of Cardiology, 41(2), 60-69.

Hidayati, Deny. (2020). Profil Penduduk Terkonfirmasi Positif Covid-19 Dan Meninggal: Kasus Indonesia Dan Dki Jakarta. Jurnal Kependudukan Indonesia, 93-100.

Ilpaj, Salma Matla, \& Nurwati, Nunung. (2020). Analisis pengaruh tingkat kematian akibat COVID-19 terhadap kesehatan mental masyarakat di Indonesia. Focus: Jurnal Pekerjaan Sosial, 3(1), 16-28.

Isna, Hikmawati, \& Ragil, Setiyabudi. (2020). Hipertensi dan Diabetes Militus Sebagai Penyakit Penyerta Utama Covid-19 di Indonesia Hypertension And Diabetes Mellitus As Covid-19 Comorbidities In Indonesia. Seminar Nasional Hasil Penenlitian Dan Pengabdian Pada Masyarakat V Tahun 2020 "Pengembangan Sumber Daya Menuju Masyarakat Madani Berkearifan Lokal."

Kangdra, Windy Yoanna. (2021). Karakteristik Klinis dan Faktor Komorbid pada Pasien dalam Pengawasan (PDP) Coronavirus Disease 2019 (COVID-19) di RS Mitra 
Medika Amplas.

Larasati, Dwi. (2021). Peningkatan Informasi Penyakit Dengan Komorbid Hipertensi Pada Masa Pandemi Covid-19 Di Puskesmas Piyungan. Abdimas Madani, 3(1), 2125.

Mujiburrahman, Mujiburrahman, Riyadi, Muskhab Eko, \& Ningsih, Mira Utami. (2020). Hubungan Pengetahuan dengan Perilaku Pencegahan Covid-19 di Masyarakat. Jurnal Keperawatan Terpadu (Integrated Nursing Journal), 2(2), 130-140.

Ridlo, Ilham Akhsanu. (2020). Pandemi Covid-19 dan tantangan kebijakan kesehatan mental di Indonesia. INSAN Jurnal Psikologi Dan Kesehatan Mental, 5(2), 162171.

Rizal, Muhammad, Afrianti, Ria, \& Abdurahman, Iman. (2021). Dampak Kebijakan Pemberlakuan Pembatasan Kegiatan Masyarakat (PPKM) bagi Pelaku Bisnis Coffe shop pada Masa Pandemi Terdampak COVID-19 di Kabupaten Purwakarta. Jurnal Inspirasi, 12(1), 96-105.

Satria, Raden Muhammad Ali, Tutupoho, Resty Varia, \& Chalidyanto, Djazuly. (2020). Analisis Faktor Risiko Kematian dengan Penyakit Komorbid Covid-19. Jurnal Keperawatan Silampari, 4(1), 48-55.

Siagian, Tiodora Hadumaon. (2020). Mencari kelompok berisiko tinggi terinfeksi virus corona dengan discourse network analysis. Jurnal Kebijakan Kesehatan Indonesia: JKKI, 9(2), 98-106.

Susilo, Adityo, Rumende, Cleopas Martin, Pitoyo, Ceva Wicaksono, Santoso, Widayat Djoko, Yulianti, Mira, Herikurniawan, Herikurniawan, Sinto, Robert, Singh, Gurmeet, Nainggolan, Leonard, \& Nelwan, Erni Juwita. (2020). Coronavirus disease 2019: Tinjauan literatur terkini. Jurnal Penyakit Dalam Indonesia, 7(1), 4567.

Tarigan, Setia Putra. (2021). Hubungan Riwayat Penyakit Hipertensi, Jantung dan Diabetes dengan Kerentanan Menderita Covid-19 pada Rumah Sakit Mitra Sejati Medan Periode Maret 2020-Oktober 2020.

Willim, Herick A., Ketaren, Infan, \& Supit, Alice I. (2020). Dampak Coronavirus Disease 2019 terhadap Sistem Kardiovaskular. E-CliniC, 8(2).

Yuliana, Yuliana. (2020). Corona virus diseases (Covid-19): Sebuah tinjauan literatur. Wellness And Healthy Magazine, 2(1), 187-192.

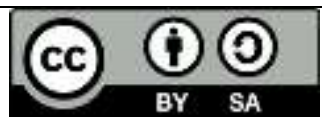

This work is licensed under a Creative Commons Attribution-ShareAlike 4.0 International License. 